\title{
UDZIELANIE SAKRAMENTU CHRZTU OSOBOM PONIŻEJ 14. ROKU ŻYCIA W PRAWIE PARTYKULARNYM ARCHIDIECEZJI LUBELSKIEJ
}

\section{Wstęp}

Sakrament chrztu świętego jako „brama wejściowa do życia w Duchu” oraz "drzwi, które otwierają wstęp do innych sakramentów” stanowi fundament życia chrześcijańskiego ${ }^{1}$. Jest on „konieczny do zbawienia dla tych, którym była głoszona Ewangelia i którzy mieli możliwość proszenia o ten sakrament" ${ }^{\prime 2}$. Najważniejsze elementy katolickiej teologii chrztu zostały sprecyzowane w uchwałach Soboru Watykańskiego $\mathrm{II}^{3}$. Pozostają one w bezpośredniej relacji z normami kanonicznymi. Wpłynęły

* Dr, Katolicki Uniwersytet Lubelski Jana Pawła II; e-mail: adjaszcz@kul.pl, https:/ / orcid.org/0000-0003-2282-1523.

1 Catechismus Catholicae Ecclesiae, Città del Vaticano 1997. Katechizm Kościoła Katolickiego, wyd. 2, Poznań 2012 (dalej: KKK), 1213; Codex Iuris Canonici Pii X Pontificis Maximi iussu digestus Benedicti Papae XV auctoritate promulgatus (27.05.1917 r.), Acta Apostolicae Sedis (dalej: AAS) 9(1917), pars II, s. 1-593 (dalej: KPK 1917), kan. 737 § 1.

2 KKK 1257.

3 Sacrosanctum Concilium Oecumenicum Vaticanum II, Decretum de activitate missionali Ecclesiae "Ad gentes Divinitus" (7.12.1965 r.), AAS 58(1966), s. 947-990. Sobór Watykański II, Konstytucje, dekrety, deklaracje, tekst polski, nowe tłumaczenie, red. M. Przybył, Poznań 2002, s. 433-471, nr 6, 14; Sacrosanctum Concilium Oecumenicum Vaticanum II, Decretum de presbyterorum ministerio et vita "Presbyterorum ordinis" (7.12.1965 r.), AAS 58(1966), s. 991-1024. Sobór Watykański II, Konstytucje, dekrety, deklaracje, s. 478-507, nr 5; Sacrosanctum Concilium Oecumenicum Vaticanum II, Constitutio dogmatica de Ecclesia "Lumen gentium” (21.11.1964 r.), AAS 57(1965), s. 5-75. Sobór Watykański II, Konstytucje, dekrety, deklaracje, s. 141-150, nr 11; Sacrosanctum Concilium Oecumenicum Vaticanum II, Decretum 
zarówno na zredagowanie nowego Ordo baptismi parvulorum ${ }^{4}$, ogłoszonego dnia 15 maja 1969 r., jak również przepisów kodeksowych ${ }^{5}$ O chrzcie (kan. 849-878) .

Biskupi diecezjalni $w$ trosce o wiernych wydają normy porządkujące sprawowanie sakramentu chrztu w powierzonych im Kościołach partykularnych. Przedmiotem niniejszego artykułu jest ukazanie stanu prawnego w archidiecezji lubelskiej w zakresie chrztu małoletnich ${ }^{7}$, którzy nie ukończyli 14. roku życia, wynikających z tego implikacji duszpasterskich i administracyjnych, a także próba oceny tych przepisów. Po promulgacji KPK 1983 udzielanie chrztu dzieciom w archidiecezji lubelskiej zostało uregulowane w statutach II Synodu Diecezji Lubelskiej (1977-1985) ${ }^{8}$ oraz w Instrukcji o udzielaniu sakramentu chrztu w Archidiecezji Lubelskiej z dnia 28 kwietnia 2017 r. (Nr 232/Gł/2017)9. Wydanie instrukcji spowodowało, że straciły moc wszystkie wcześniejsze przepisy diecezjalne dotyczące udzielania chrztu w archidiecezji lubelskiej, także te, które wymagałyby specjalnej wzmianki ${ }^{10}$. Chrzest osób, które ukończyły 14 . rok

de apostolatu laicorum "Apostolicam actuositatem” (18.11.1965 r.), AAS 58(1966), s. 837-864. Sobór Watykański II, Konstytucje, dekrety, deklaracje, s. 377-401, nr 2.

4 Ordo baptismi parvulorum, editio typica, Typis Polyglottis Vaticanis 1969, $1973^{2}$. Obrzędy chrztu dzieci wedtug Rytuatu Rzymskiego, Katowice 1972 oraz Obrzędy chrztu dzieci dostosowane do zwyczajów diecezji polskich, Katowice $1987^{2}, 1992^{3}, 1994^{4}$. W artykule wykorzystano polski tekst rytuału z 1987 r., który opiera się na drugim wydaniu typicznym tekstu łacińskiego i uwzględnia zmiany wprowadzone przez Kodeks Prawa Kanonicznego z 1983 r. (dalej: OCHD 1987).

5 Codex Iuris Canonici auctoritate Ioannis Pauli PP. II promulgatus (25.01.1983 r.), AAS 75(1983), pars II, s. 1-317 (dalej: KPK 1983).

6 L. Gerosa, Prawo Kościota, t. 12, Poznań 1999, s. 187-188.

7 Osoba, która nie ukończyła 18. roku życia, jest uważana w prawie kanonicznym za małoletnią (persona minor). Przed 7. rokiem życia nazywa się ją dzieckiem (infans) i uważa za niezdolną do kierowania swoim postępowaniem. Wykonując swoje uprawnienia, osoba małoletnia jest uzależniona od władzy rodziców i opiekunów, czego wyrazem są przepisy dotyczące udzielania chrztu dzieciom (KPK 1983, kan. 97 § 1-2), T. Pawluk, Prawo kanoniczne wedtug Kodeksu Jana Pawła II, t. 1. Zagadnienia wstępne i normy ogólne, Olsztyn 2015, s. 254.

8 II Synod Diecezji Lubelskiej 1977-1985, Lublin 1988 (dalej: II SDL).

9 Arcybiskup Metropolita Lubelski, Instrukcja o udzielaniu sakramentu chrztu w Archidiecezji Lubelskiej, Wiadomości Archidiecezji Lubelskiej „Memoranda” 2017, t. 91, nr 2, s. 259-270 (dalej: ICHAL).

10 ICHAL, 48. 
życia, jak również chrzest małoletnich poniżej tego wieku, został na nowo uregulowany stosownymi przepisami zawartymi w $\mathrm{ICHAL}^{11}$.

\section{Wymogi do udzielenia sakramentu}

\section{Prośba rodziców}

Dzieci należy chrzcić w pierwszych tygodniach ich życia ${ }^{12}$. Sakrament ten jest często nazywany „bramą sakramentów"13. Określenie to nawiązuje do słów samego Jezusa, który nauczał o konieczności duchowego odrodzenia jako o pierwszym i podstawowym warunku zbawienia wieczne-

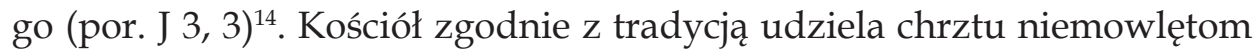
na prośbę ich rodziców lub opiekunów. Nie zmienia to faktu, że także chrzest małych dzieci jest sakramentem wiary, wprawdzie nie ich własnej, ale wiary Kościoła wyznawanej publicznie przez rodziców, chrzestnych i całą wspólnotę reprezentującą Kościół powszechny ${ }^{15}$.

Podstawą do udzielenia chrztu dzieciom poniżej 14. roku życia jest więc prośba lub zgoda wyrażona przynajmniej przez jednego z rodziców lub prawnych opiekunów. Dotyczy to również sytuacji, w której jedno z rodziców jest katolikiem lub w której o chrzest prosi rodzic samotnie wychowujący dziecko. Oznacza to, że poza sytuacją niebezpieczeństwa śmierci nie wolno ochrzcić dziecka bez wiedzy, a tym bardziej bez zgody rodziców lub opiekunów prawnych. W przypadku tych ostatnich, także rodziców zastępczych, dochodzi też powinność uzgodnienia zamiaru chrztu, jeśli to możliwe, z rodzicami biologicznymi dziecka ${ }^{16}$.

11 Osoba, która ukończyła 14. rok życia, samodzielnie prosi o sakramenty wtajemniczenia chrześcijańskiego. Zasady przygotowania tych osób (katechumenatu) regulują odrębne przepisy (tamże, 11).

12 II SDL, 206.

13 Zob. kan. 737 § 1 KPK 1917; kan. 849 KPK 1983; OCHD/87, Wtajemniczenie chrześcijańskie, 3.

14 Zob. J. Krzywda, Chrzest, w: W. Góralski i in., Komentarz do Kodeksu Prawa Kanonicznego, t. 3, cz. 2, ks. 4. Uświęcające zadanie Kościoła, cz. 1. Sakramenty, cz. 2. Pozostałe akty kultu Bożego, cz. 3. Miejsca i czasy święte, Poznań 2011, s. 36.

15 Zob. II SDL 205; T. Rincón-Pérez, La liturgia e i sacramenti nel diritto della Chiesa, Roma 2014, s. 168.

16 ICHAL, 1-3. 
Ilekroć w ICHAL jest mowa o „rodzicach dziecka”, należy to odnieść także do rodziców, którzy dokonali przysposobienia (rodziców adopcyjnych) oraz do opiekunów prawnych, np. rodziców zastępczych ${ }^{17}$.

\section{Wychowanie w wierze Kościoła}

Należy postawić pytanie, jak powinni zachować się duszpasterze, gdy rodzice lub opiekunowie prawni nie są w stanie zagwarantować, że dziecko zostanie wychowane w wierze Kościoła katolickiego lub też szczerość zapewnienia budzi uzasadnione wątpliwości. Czy wspólnota chrześcijańska może w jakiś sposób uzupełnić deklaracje składane przez rodziców? W powyższej sytuacji ICHAL rozpatruje dwa przypadki. Po pierwsze, w razie braku dostatecznej gwarancji ze strony rodziców wystarczającą rękojmią może być wybór takich chrzestnych, którzy podejmą się troski o wychowanie katolickie dziecka, lub też pomoc ze strony wspólnoty wierzących. Przedstawienie chrzestnych, którzy zajmą się wychowaniem dziecka w wierze Kościoła, można uznać za wystarczającą gwarancję. Po drugie, jeśli nie ma nadziei na wychowanie dziecka w wierze, to znaczy nie gwarantują tego rodzice oraz ewentualni chrzestni, a także niemożliwa jest pomoc ze strony wspólnoty wierzących, udzielenie sakramentu należy odłożyć w czasie. Przyczyna takiej decyzji powinna być wyjaśniona rodzicom. Należy zaznaczyć, że nie chodzi o odmowę sakramentu, ale o jego czasowe przesunięcie. ICHAL zastrzega jednak, że w polskich warunkach tego typu sytuacje należą do rzadkości, dlatego też nakłada się na duszpasterzy obowiązek skonsultowania takiej decyzji z Kurią Metropolitalną. Z uwagi na konieczność chrztu do zabawienia ${ }^{18}$, w przypadku wątpliwości co do jego udzielenia lub przesunięcia w czasie, należy opowiedzieć się za pierwszym rozwiązaniem ${ }^{19}$.

Sformułowanie „wychowanie dziecka w wierze Kościoła” nie jest pojęciem abstrakcyjnym i zawiera w sobie konkretne działania ze strony rodziców i wspólnoty chrześcijańskiej. ICHAL recypuje cele związane z wychowaniem w wierze zawarte w Instrukcji duszpasterskiej o udzielaniu sakramentu chrztu świętego Konferencji Episkopatu Polski² ${ }^{20}$ Wy-

17 Tamże, 22.

18 Zob. KKK, nr 1213.

19 ICHAL, 7.

20 Konferencja Episkopatu Polski, Instrukcja duszpasterska Episkopatu o udzielaniu sakramentu chrztu świętego dzieciom (1975), w: Dokumenty duszpastersko-liturgiczne Episkopatu Polski 1966-1993, oprac. C. Krakowiak, L. Adamowicz, Lublin 1994, s. 13-21, nr 2. 
chowanie w wierze oznacza: doprowadzenie dziecka do świadomej przyjaźni z Chrystusem, przekazanie podstawowych prawd wiary i zasad moralności głoszonych przez Kościół katolicki, nauczenie dziecka modlitwy, włączenie go w życie wspólnoty poprzez Mszę Świętą niedzielną, posyłanie na naukę religii, doprowadzenie do pełnego udziału w Eucharystii i do przyjęcia sakramentu bierzmowania oraz wprowadzenie w dojrzałe i odpowiedzialne życie chrześcijańskie. Wymienione wymagania należy uwzględnić w konferencjach przed przyjęciem sakramentu chrztu. Osoby odpowiedzialne za wychowanie dziecka już w pierwszych latach jego życia powinny zdawać sobie sprawę z przyjętych zobowiązań. Wychowanie do decyzji o przyjęciu sakramentu bierzmowania jako potwierdzenia aktu rodziców proszących o chrzest i wyznających wiarę w zastępstwie swojego dziecka, jak również wprowadzanie w dojrzałe i odpowiedzialne chrześcijaństwo, rozpoczyna się już w pierwszych latach życia nowo ochrzczonego ${ }^{21}$.

ICHAL recypuje też rozstrzygnięcia Konferencji Episkopatu Polski w materii innych sytuacji duszpasterskich związanych z chrztem dzieci² ${ }^{22}$ Wszelkie ograniczenia nie obowiązują w sytuacji zagrożenia życia. Jeśli rodzice pozostają w małżeństwie cywilnym lub w związku nieformalnym, duszpasterz powinien starać się o doprowadzenie ich do zawarcia małżeństwa kanonicznego przed chrztem. Troska o wychowanie w wierze jest jednocześnie troską o życie sakramentalne rodziców. Duszpasterz powinien jednak wystrzegać się jakiejkolwiek formy nacisku wobec rodziców w kwestii zawarcia małżeństwa kanonicznego ${ }^{23}$. Staje się ono nieważne, jeżeli małżeństwo jest dla kontrahenta jedynym sposobem uwolnienia się od bojaźni, niezależnie od intencji sprawcy bojaźni, nawet wówczas, gdyby bojaźń spowodowana była przyczyną konieczną jakiegokolwiek rodzaju ${ }^{24}$.

Zakazuje się żądania od rodziców oświadczenia na piśmie, że zobowiązują się do zawarcia sakramentalnego małżeństwa jako warunku udzielenia chrztu. Należy natomiast wymagać oświadczenia na piśmie od rodziców odmawiających definitywnie zawarcia małżeństwa kanonicznego, że zobowiązują się wychować dziecko w wierze katolickiej. Takie

21 ICHAL, 8.

22 Konferencja Episkopatu Polski, Instrukcja duszpasterska..., nr 2.

23 ICHAL, 9a.

24 Zob. U. Navarrete, Responsa Pontificiae Commissionis Codici Iuris Canonici authentice interpretando, Periodica de Re Morali Canonica Liturgica 1988, t. 77, s. 506. 
samo oświadczenie mają obowiązek złożyć chrzestni. Dotyczy to również sytuacji, w których rodzice nie zawierają ślubu kościelnego z powodu przeszkód kanonicznych. Duszpasterz powinien poinformować rodziców o możliwości bezpłatnej konsultacji w sądzie metropolitalnym odnośnie do ewentualnego procesu o stwierdzenie nieważności poprzedniego małżeństwa. Nie odmawia się chrztu w sytuacji, gdy jedno z rodziców jest wyznania katolickiego, a drugie deklaruje się jako osoba niewierząca ${ }^{25}$.

W przypadku rodzin religijnie obojętnych o dopuszczeniu do chrztu dzieci decyduje miejscowy duszpasterz, mając na uwadze świętość sakramentu, zobowiązanie do wychowania w wierze oraz dalszy udział dzieci w życiu sakramentalnym Kościoła. Należy unikać postawy zbyt liberalnej, jak również nadmiernego rygoryzmu ${ }^{26}$. Decyzję $w$ sprawie chrztu ostatecznie podejmuje proboszcz, który spotkanie z rodzicami w biurze parafialnym powinien potraktować jako okazję do oddziaływania duszpasterskiego ${ }^{27}$. Ustawodawca w kan. 530 n. 1 KPK 1983 wymienia udzielanie chrztu jako jedną z czynności specjalnie powierzonych proboszczowi. Tym samym własny proboszcz, nie wikariusz, ma pierwszeństwo w udzielaniu tego sakramentu.

W sytuacji kandydatów, którzy ukończyli 14. rok życia, pierwszeństwo w udzielaniu sakramentów wtajemniczenia chrześcijańskiego ma biskup diecezjalny (kan. 863 KPK 1983). Oznacza to, że przygotowując taką osobę do chrztu na terenie archidiecezji lubelskiej, należy powiadomić o tym biskupa diecezjalnego.

\section{Przygotowanie}

Udzielenie sakramentu powinno poprzedzać odpowiednie przygotowanie rodziców i chrzestnych, tak aby mogli właściwie wykonywać obowiązki religijne wynikające $\mathrm{z}$ chrztu dziecka ${ }^{28}$. W każdej parafii mają odbywać się specjalne katechezy przedchrzcielne. Formacja, obok wprowadzenia w teologię chrztu, obejmuje wyjaśnienie obrzędów tego sakramentu i jego symbolikę. Dla ogółu wiernych odpowiednim momentem na katechezę związaną z sakramentem chrztu jest okres Wielkiego Postu ${ }^{29}$.

\footnotetext{
25 ICHAL, 9a-b, 10.

26 II SDL, 83.

27 ICHAL, 18.

28 Zob. T. Rincón-Pérez, La liturgia e i sacramenti..., s. 169.

29 II SDL, 56-57, 83-84.
} 
Duszpasterze mają zadbać o systematyczne prowadzenie katechez przygotowujących rodziców i chrzestnych. Terminy, jak również ich częstotliwość, zależą od miejscowych potrzeb. Szczególnej trosce duszpasterzy powierza się tych rodziców, którzy nie są należycie zaangażowani w życie sakramentalne. Wprowadza się obowiązek odbycia z nimi przynajmniej trzech spotkań, w czasie których zostanie podjęta próba ożywienia ich życia religijnego ${ }^{30}$.

Dzieci w wieku katechetycznym (7-14 lat), które wyrażają wolę przyjęcia chrztu, powinny przejść okres przygotowania obejmującego naukę prawd wiary, zasad życia chrześcijańskiego i wtajemniczenie w sakramentalne życie Kościoła, dostosowane do ich poziomu rozwojowego. Poprzez udział w katechizacji i obrzędach liturgicznych mają stopniowo dojrzewać, aby w odpowiednim czasie, w sposób wolny, podjęły decyzję o przyjęciu chrztu ${ }^{31}$. Wymagana jest też prośba lub zgoda wyrażona przynajmniej przez jednego z rodziców bądź prawnych opiekunów. W czasie jednej ceremonii liturgicznej udziela się chrztu razem z komunią świętą, gdy przyjmującym sakramenty jest dziecko z klasy IV szkoły podstawowej lub starsze ${ }^{32}$.

\section{Sporządzanie dokumentów w biurze parafialnym}

\section{Akt chrztu}

Zgodnie z zasadą ubi factus - ibi actus proboszcz miejsca udzielania chrztu ma obowiązek odnotowania tego faktu w księdze ochrzczonych, prowadzonej w każdej parafii. Za treść aktu odpowiada osobiście proboszcz, niezależnie od tego, czy szafarzem chrztu był inny duchowny lub też czy czynności kancelaryjne wykonywała inna osoba ${ }^{33}$. Akt chrztu sporządza się na podstawie cywilnego skróconego odpisu aktu urodzenia. Dokument ten należy przedstawić w biurze parafialnym do wglądu. Duszpasterz po dokonaniu formalności powinien zwrócić odpis

30 ICHAL, 12.

31 II SDL, 84.

32 Bierzmowania udziela się w innym czasie, wraz z grupą rówieśniczą, ICHAL, 4.

33 Zob. K. Mikołajczuk, Realizacja zasady jedności sakramentów wtajemniczenia chrześcijańskiego w prawodawstwie Kościoła Katolickiego, Kielce 2006, s. 224-225. 
aktu urodzenia rodzicom. Akt chrztu sporządza się w dwóch egzemplarzach (unikat i duplikat). Swoje podpisy składają na nim następujące osoby: przynajmniej jeden rodzic lub prawny opiekun, przynajmniej jeden chrzestny, proboszcz, a także świadek chrztu i pełnomocnik chrzestnego, jeśli uczestniczą $\mathrm{w}$ celebracji ${ }^{34}$.

Jeżeli udziela się chrztu w niebezpieczeństwie śmierci poza kościołem, zaleca się po wyzdrowieniu przyniesienie dziecka do kościoła, aby przedstawić je wspólnocie parafialnej ${ }^{35}$. Jeśli chrzest został udzielony w sytuacji konieczności, np. w szpitalu, szafarz powinien wystawić zaświadczenie o udzielonym chrzcie oraz pouczyć o konieczności sporządzenia aktu w parafii zamieszkania na podstawie otrzymanego zaświadczenia. Kapelani szpitalni mogą prowadzić własny rejestr. Nie mogą jednak wydawać wiernym świadectw chrztu ${ }^{36}$.

W sytuacji błędnego wpisania danych aktu chrztu lub ich zmiany osoba ochrzczona, jej rodzice lub prawni opiekunowie mogą zwrócić się do proboszcza parafii, w której znajduje się rejestr ochrzczonych, o dokonanie właściwej korekty. Konieczne jest też zezwolenie ordynariusza miejsca. Występuje o nie proboszcz parafii, który powinien załączyć do wniosku stosowne dokumenty (lub ich uwierzytelnione kopie), uzasadniające dokonanie zmiany ${ }^{37}$.

W przypadku chrztu dziecka przysposobionego (adoptowanego) oraz w przypadku przysposobienia dziecka już ochrzczonego zachowuje się przepisy wydane przez Konferencję Episkopatu Polski ${ }^{38}$. W dniu 19 czerw-

34 ICHAL, 26.

35 II SDL, 83; „W niebezpieczeństwie bowiem bliskiej śmierci wystarczy, by udzielający, opuszczając inne obrzędy, polał dziecko wodą, wymawiając równocześnie zwykłą formułę. Wypada, aby udzielający chrztu czynił to w miarę możliwości w obecności jednego lub dwóch świadków", OCHD, 138.

36 ICHAL, 27.

37 ICHAL, 28.

38 ICHAL, 30. W przeszłości kanoniści podejmowali próby sformułowania propozycji w tej materii de lege ferenda. Takie przepisy miały uwzględniać wiele czynników: nowy status cywilny i kanoniczny osoby, poufność danych, prawo do prywatności, prawo do własnej tożsamości oraz interes publiczny, który należy rozumieć jako z jednej strony zgodność z legislacją cywilną (kan. 877 § 3 KPK/83), z drugiej prawo Kościoła do należytej weryfikacji stanu wolnego (wolności od przeszkód) osób zwierających małżeństwo kanoniczne. P. Majer nie widział potrzeby tworzenia w warunkach polskich specjalnego rejestru osób adoptowanych czy centralizacji danych w tajnym archiwum kurii. Jak twierdzili niektórzy, taka praktyka byłaby gwarancją większej ochrony danych. Z drugiej strony, 
ca 2018 r. został promulgowany Dekret ogólny dotyczący sporządzenia i modyfikacji aktu chrztu w związku z przysposobieniem. Konferencja Episkopatu Polski postanowiła ujednolicić zasady sporządzenia i modyfikacji aktu chrztu w związku z przysposobieniem (adopcją). Prawomocne orzeczenie sądu rodzinnego o przyznaniu praw rodzicielskich pociąga za sobą konieczność naniesienia przez urząd stanu cywilnego zmian w akcie urodzenia osoby przysposobionej bądź sporządzenia nowego aktu urodzenia. Jeżeli chrzest nastąpił przed przysposobieniem dziecka, również w akcie chrztu muszą zostać naniesione nowe dane lub też należy sporządzić nowy akt chrztu ${ }^{39}$.

Udzielając chrztu w niebezpieczeństwie śmierci, w księdze ochrzczonych należy wpisać jako szafarza imię i nazwisko osoby, która faktycznie udzieliła sakramentu. Przepisy liturgiczne przewidują celebrację uzupełnienia obrzędów i ceremonii, której przewodniczy duchowny. Jego imię i nazwisko, a także data obrzędu, powinny zostać wpisane w akcie chrztu ${ }^{40}$.

Człowiek już ochrzczony nie może przyjąć chrztu po raz drugi, ponieważ sakrament ten jest niepowtarzalny ze względu na swój niezniszczalny charakter ${ }^{41}$. Gdy spisano już akt chrztu, choć fakt udzielenia sakramentu budzi wątpliwości, wystarczy, udzielając chrztu warunkowego, umieścić stosowną adnotację na marginesie aktu już sporządzonego. Nie trzeba spisywać go na nowo. Gdy stwierdza się brak aktu, a sam fakt udzielenia sakramentu budzi wątpliwości, udziela się chrztu warunkowego, sporządzając akt chrztu z adnotacją na marginesie o kwalifikacji prawnej tej celebracjii ${ }^{42}$.

Szafarz chrztu powinien zatroszczyć się o to, by był obecny przynajmniej jeden świadek, który w przyszłości będzie mógł potwierdzić udzielenie sakramentu. W sytuacji zwyczajnej role świadków spełniają rodzice

spowodowałaby wzrost biurokracji. Autor uważał, że ochronę tajemnicy adopcji można zapewnić poprzez inne rozwiązania. Zob. P. Majer, Tajemnica przysposobienia a przeszkoda pokrewieństwa: odnotowanie adopcji w księdze ochrzczonych (kan. 877 §3), Prawo Kanoniczne. Kwartalnik Prawno-Historyczny 2011, t. 54, nr 3-4, s. 223-246.

39 Konferencja Episkopatu Polski, Dekret ogólny dotyczący sporządzenia i modyfikacji aktu chrztu w zwiazku z przysposobieniem (14.03.2017 r.), Akta Konferencji Episkopatu Polski 2018, nr 30, s. 46-47.

40 ICHAL, 31.

${ }_{41}$ Zob. T. Pawluk, Prawo kanoniczne wedtug Kodeksu Jana Pawła II, t. 2. Lud Boży jego nauczanie i uświęcanie, Olsztyn 2010, s. 330.

42 ICHAL, 32. 
chrzestni. Jeżeli by się tak nie stało, świadkiem może być każdy, kto jest w stanie potwierdzić zaistniały fakt. W kwestii konieczności udowodnienia chrztu ustawodawca w kan. 876 KPK 1983 stwierdza, że wystarczy oświadczenie jednego wiarygodnego świadka, jeśli nie przynosi to nikomu szkody. Najlepszym środkiem dowodowym jest jednak dokument publiczny, czyli metryka chrztu. Jeśli niemożliwe byłoby przedstawienie takiego dokumentu, wymaganego przed pierwszą spowiedzią i komunią świętą czy też przed ślubem, fakt chrztu może zostać udowodniony na podstawie jednego wiarygodnego świadka, także niezaprzysiężonego. Może to być osoba wyznaczona zgodnie z kan. 875 KPK 1983 lub świadek faktyczny, np. ojciec lub matka, rodzic chrzestny, szafarz chrztu bądź inna osoba uczestnicząca w ceremonii. Fakt przyjęcia chrztu może udowodnić sam zainteresowany, jeśli przyjął sakrament po ukończeniu 7. roku życia. Jego oświadczenie powinno być zaprzysiężone. Jeśli udowodnienie chrztu mimo wszystko nie jest możliwe, dowodem jego przyjęcia, zgodnie z kan. 1584 KPK 1983, może być domniemanie oparte na dostatecznie przekonujących poszlakach. Argumentów poszlakowych dostarcza przykładowo religijna atmosfera domu rodzinnego, pamiątka Pierwszej Komunii Świętej, świadectwo bierzmowania itp. ${ }^{43}$

\section{Kopia aktu chrztu i świadectwo chrztu}

Rodzice lub prawni opiekunowie osób małoletnich, jeśli wykażą interes prawny, mogą prosić o wydanie kopii aktu lub świadectwa chrztu swojego dziecka, wystawionego na podstawie księgi ochrzczonych. Mają też prawo wyznaczyć osobę, która odbierze dokument na podstawie pełnomocnictwa. Istnieje także możliwość przesłania go do parafii zamieszkania osoby wnioskującej. W chwili odbierania dokumentu należy okazać dokument tożsamości.

Kopię aktu chrztu wykonuje dowolną techniką proboszcz lub osoba przez niego upoważniona. W tym drugim przypadku akty sąsiednie powinny zostać zasłonięte ${ }^{44}$.

Świadectwo chrztu wydaje się w języku polskim lub łacińskim. Istnieją dwie formy sporządzania tego dokumentu: pełna i skrócona. Wersja pełna obejmuje: nazwisko i imiona ochrzczonego, imiona i nazwiska rodowe rodziców, datę i miejsce urodzenia, datę i miejsce chrztu, imię i nazwisko

\footnotetext{
43 Zob. T. Pawluk, Prawo kanoniczne, t. 2. Lud Boży..., s. 332.

${ }^{44}$ ICHAL, 38-39.
} 
szafarza, przynależność do Kościoła sui iuris, wszystkie wzmianki wpisane na marginesie aktu, datę wystawienia świadectwa, podpis proboszcza i pieczęć parafialną. Zainteresowany wydaniem świadectwa może wnioskować o umieszczenie danych rodziców chrzestnych.

Skrócone świadectwo chrztu z zasady wydaje się w celu udowodnienia chrztu przed przyjęciem Pierwszej Komunii Świętej i bierzmowania. Zostaje to zaznaczone w tytule dokumentu: „Do Pierwszej Komunii św. i bierzmowania”. Wpisuje się następujące dane: nazwisko i imiona ochrzczonego, imiona i nazwiska rodowe rodziców, datę i miejsce urodzenia, datę i miejsce chrztu, przynależność do Kościoła sui iuris, datę wystawienia świadectwa, podpis proboszcza i pieczęć parafialną. Duszpasterz po zweryfikowaniu faktu chrztu powinien zwrócić dokument przedkładającej go osobie. Świadectwo chrztu wydawane jest nieodpłatnie, aczkolwiek może być złożona dobrowolna ofiara ${ }^{45}$.

\section{Chrzestni}

Zgodnie ze starożytną tradycją Kościoła chrzestny jest poręczycielem i pomocnikiem przyjmującego chrzest, jest także świadkiem udzielanego sakramentu oraz gwarantem rozwijania łaski sakramentalnej w życiu dorastającego człowieka ${ }^{46}$. Ustawodawca w kan. 873 KPK 1983 stwierdza, że przyjmujący chrzest w Kościele łacińskim powinien mieć jednego chrzestnego (mężczyznę lub kobietę) lub dwoje chrzestnych (jednocześnie jednego mężczyznę i jedną kobietę).

Proboszcz i szafarz chrztu podejmują decyzję o dopuszczeniu do zadania chrzestnego na podstawie własnego rozeznania lub aktualnego zaświadczenia wydanego przez parafię zamieszkania kandydata. W jednym i drugim przypadku należy kierować się przepisami prawa kanonicznego, które wymagają od chrzestnych, by byli wyznania katolickiego, ukończyli 15. rok życia oraz przyjęli sakramenty Eucharystii i bierzmowania. Ponadto nie mogą pozostawać w karach kanonicznych, a także być ojcem lub matką przyjmującego chrzest. Tym samym wyklucza się osoby żyjące

45 Tamże, 42-45.

46 Zob. L. Adamowicz, Wprowadzenie do prawa o sakramentach świętych wedtug Kodeksu Prawa Kanonicznego oraz Kodeksu Kanonów Kościołów Wschodnich, Lublin 1999, s. 75. 
bez małżeństwa kanonicznego (w tym związane cywilnie), odstępców od wiary, osoby niepraktykujące, uczniów, którzy zrezygnowali z uczestniczenia w lekcjach religii oraz osoby publicznie manifestujące przekonania niedające się pogodzić z nauczaniem Kościoła katolickiego. Ewentualną odmowę dopuszczenia takich osób do zadania chrzestnego uzasadnia się ich niezdolnością do wspierania rodziców w katolickim wychowaniu dziecka.

Zarówno proboszcz, jak i szafarz chrztu mogą dopuścić do zadania chrzestnego osobę młodszą, niż przewidują to przepisy. Musi ona jednak spełniać wszystkie wymienione wyżej wymagania ${ }^{47}$.

Chrzestnym może zostać chrześcijanin z Kościoła prawosławnego, jednak zawsze razem z pierwszym chrzestnym katolikiem. Pozostali chrześcijanie niekatolicy, jeśli nie chodzi o osobę, która odstąpiła od pełnej jedności z Kościołem katolickim wskutek schizmy lub apostazji, mogą pełnić funkcję świadka chrztu. Tym bardziej w takim przypadku pierwszym chrzestnym powinna być osoba wyznania katolickiego. Funkcja świadka chrztu nie jest przeznaczona dla katolików, którzy ze względu na osobistą sytuację nie spełniają wymogów stawianych kandydatom na chrzestnych $^{48}$.

Jeśli istnieją ku temu ważne przyczyny, zadania chrzestnego można podjać przez pełnomocnika, który otrzymał pisemne pełnomocnictwo od swego mocodawcy. Taki dokument powinien zawierać: dane personalne

47 ICHAL, 33. We wrześniu 2015 r. Kongregacja Nauki Wiary w odpowiedzi na wątpliwość i oficjalne zapytanie biskupa Kadyksu i Ceuty w Hiszpanii stwierdziła, że do zadania chrzestnego nie mogą być dopuszczane osoby transseksualne. Dykasteria oznajmiła, że zachowania transseksualne ukazują postawę sprzeczną z wymaganiami moralnymi stawianymi kandydatom na chrzestnych, dlatego też nie powinno się dopuszczać osób transseksualnych do tego właśnie zadania. Jednocześnie stwierdzono, że nie może być tu mowy o dyskryminacji, ale o rozeznaniu obiektywnego braku odnośnie do wymagań, które ze swej natury są konieczne do przyjęcia odpowiedzialności chrzestnego. W odpowiedzi Kongregacji udzielonej biskupowi zacytowano nr 155 encykliki Laudato sii, w której papież Franciszek stwierdził, że „docenienie własnego ciała w jego kobiecości lub męskości jest konieczne, aby móc rozpoznać siebie w spotkaniu z innym, różnym od siebie. W ten sposób można z radością przyjąć specyficzny dar drugiego czy drugiej jako dzieła Boga Stwórcy i wzajemnie się ubogacić. Z tego względu nie jest zdrowa postawa usiłująca zatrzeć różnicę płci, bo nie potrafi z nią się konfrontować”. Zob. J. González Grenon, La congruencia entre fe y vida para ser padrino de bautismo y de confirmación, Anuario Argentino de Derecho Canónico 2016, t. 22, s. 343-350.

48 ICHAL, 34-35. 
mocodawcy (chrzestnego) i pełnomocnika oraz imię i nazwisko kandydata do chrztu. Należy również dołączyć zaświadczenie dotyczące spełniania przez kandydata na chrzestnego odpowiednych wymagań kanonicznych. Pełnomocnik, oprócz wykonywania zadań wynikających z reprezentowania mocodawcy, jest jednocześnie świadkiem chrztu. W imieniu mocodawcy oznajmia, że tenże podejmuje zobowiązania o charakterze religijnym. Pełnomocnik powinien być katolikiem lub przynajmniej ochrzczonym niekatolikiem, z zachowaniem zasady dopuszczania tych osób do funkcji wraz z chrzestnym katolikiem. Nazwisko pełnomocnika należy zapisać w akcie chrztu ${ }^{49}$.

Nie wyklucza się możliwości wyznaczenia substytuta (zastępcy) chrzestnego w uzasadnionych, życiowych okolicznościach. Przykładowe sytuacje zostały wyliczone w ICHAL: apostazja lub schizma dokonana przez chrzestnego, zaprzestanie praktykowania życia sakramentalnego, wejście $\mathrm{w}$ związek niekanoniczny lub też utrata kwalifikacji religijnych bądź moralnych do pełnienia tego zadania. Zgodnie z listem Kongregacji ds. Kultu Bożego i Dyscypliny Sakramentów z 1984 r. biskup diecezjalny może wyznaczyć w takiej sytuacji, na prośbę rodziców lub opiekunów prawnych, substytuta (zastępcę) chrzestnego. Osoba ta powinna złożyć oświadczenie o przyjęciu zobowiązań wobec proboszcza lub jego delegata. Nazwisko substytuta należy wpisać do aktu chrztu ${ }^{50}$.

\section{Próba oceny obecnego stanu prawnego}

II SDL to osiem dokumentów dotyczących „węzłowych zagadnień życia diecezjalnego". Na ich podstawie Komisja Koordynacyjno-Redakcyjna synodu stworzyła zestaw postanowieńn ${ }^{51}$. Zalecenia dotyczące chrztu znajdują się w rozdziale trzecim, zatytułowanym „Życie liturgiczne". Opisuje się w nim wszystkie sakramenty Kościoła oraz ich sprawowanie w diecezji lubelskiej. Podrozdział B) dotyczy sakramentu chrztu świętego (II SDL 204-208).

\footnotetext{
49 ICHAL, 36.

50 Tamże, 37.

51 B. Pylak, Stowo wprowadzające do Uchwat synodalnych, w: II SDL, s. 8.
} 
Wydanie statutów II SDL należy uznać za wydarzenie odległe w czasie i $\mathrm{z}$ tego powodu $\mathrm{w}$ wielu aspektach nieaktualne oraz anachroniczne. Przez kolejne dekady zmieniały się warunki pracy duszpasterskiej, pojawiały się nowe wyzwania, zmieniła się mentalność wiernych. Zgodnie z zasadą, że prawo powinno podążać za życiem, niewątpliwie istnieje potrzeba stworzenia nowego ustawodawstwa partykularnego, także w materii udzielania sakramentu chrztu. Problem ten został dostrzeżony przez arcybiskupa lubelskiego, który w dniu 25 marca 2019 r. zwołał III Synod Archidiecezji Lubelskiej. Jednym z jego celów będzie "adaptowanie prawa i norm Kościoła powszechnego do konkretnej sytuacji w diecezji”. Zgromadzenie ma odnowić życie religijne, poszukiwać skutecznych metod działalności apostolskiej, ożywić istniejące dzieła i inicjatywy oraz stosownie odpowiedzieć na wyzwania współczesności ${ }^{52}$.

ICHAL jest narzędziem prawnym wyjaśniającym przepisy, a także rozwijającym i określającym racje, które należy uwzględnić przy ich zachowaniu. Instrukcje jako ogólne dyspozycje wewnętrznych organów kościelnych kieruje się do organów władzy i osób pełniących urzędy, którym powierza się wykonywanie ustaw. Należy stwierdzić, że w archidiecezji lubelskiej taki dokument był od dawna oczekiwany. Wydanie aktu normatywnego $w$ tej właśnie formie ma na celu przypomnienie i właściwe aplikowanie w archidiecezji zasad udzielania sakramentu chrztu zawartych w doktrynie i praktyce Kościoła powszechnego, a także aktualnych przepisach Konferencji Episkopatu Polski.

Z uznaniem należy się odnieść do konkretnych pomocy mających znaczenie z punktu widzenia duszpasterskiego i administracyjnego. Do ICHAL dołączono 13 formularzy kancelaryjnych (załączników) ${ }^{53}$ : informację o kandydacie do sakramentów wtajemniczenia chrześcijańskiego, który ukończył 14. rok życia; przysięgę katechumena; przysięgę katechumena związanego małżeństwem; oświadczenie świadka o braku chrztu i stanie wolnym katechumena; zezwolenie na chrzest poza parafią zamieszkania; oświadczenie rodziców i chrzestnych w sprawie wychowania katolickiego dziecka, gdy rodzice nie są związani małżeństwem kanonicznym; zaświadczenie o udzielonym sakramencie chrztu;

52 Archiwum Kurii Metropolitalnej w Lublinie, Arcybiskup Metropolita Lubelski, Dekret zwołania III Synodu Archidiecezji Lubelskiej (Nr 171/Gt/2019).

53 Zob. Formularze kancelaryjne do Instrukcji o udzielaniu chrztu w archidiecezji lubelskiej, Wiadomości Archidiecezji Lubelskiej „Memoranda” 2017, t. 91, nr 3, s. 441-455. 
prośba o zezwolenie na dokonanie zmian w akcie chrztu; zaświadczenie dla rodziców chrzestnych i świadka bierzmowania; pełnomocnictwo do podjęcia funkcji chrzestnego; prośbę o ustanowienie zastępcy (substytuta chrzestnego); świadectwo chrztu; świadectwo chrztu do Pierwszej Komunii Świętej i bierzmowania.

Procedura w sytuacji przesunięcia chrztu wydaje się być zbyt ogólnikowa. Nie zawsze duszpasterze są w stanie właściwie ocenić i rozeznać konkretny przypadek. Pozostawia to pole dla swoistej arbitralności. Pewnym zabezpieczeniem jest jednak stwierdzenie, że w polskich warunkach przesunięcie chrztu jest czymś rzadkim, dlatego konieczna jest konsultacja z kurią. Przykładem procedury opracowanej szczegółowo są przepisy wydane przez Konferencję Episkopatu Niemiec. Odłożenie chrztu jest możliwe jedynie w sytuacji, gdy rodzice dziecka odmówią rozmowy z duszpasterzem na temat pogłębienia motywacji, na podstawie której proszą o chrzest albo też gdy żaden chrzestny nie jest gotowy wziąć na siebie odpowiedzialności za wychowanie w wierze katolickiej. Proboszcz lub szafarz chrztu nie może podjąć decyzji o odłożeniu sakramentu samodzielnie, ma prawny obowiązek skonsultowania tego z dziekanem. Należy poinformować rodziców o motywach odłożenia chrztu. Ciekawym rozwiązaniem jest przepis, na podstawie którego każdego roku ordynariusz miejsca otrzymuje raport dotyczący ewentualnego odkładania chrztu dzieci ${ }^{54}$.

ICHAL pozwala na udzielenie chrztu poza miejscem świętym, gdy uzyska się zgodę ordynariusza miejsca. Dotyczy to również celebracji w ramach spotkań ruchów i wspólnot duszpasterskich. W świetle instrukcji szafarz chrztu ma „moralny i prawny obowiązek dołożenia staranności $\mathrm{w}$ wymienionych kwestiach, włącznie $\mathrm{z}$ upewnieniem się o sporządzeniu aktu chrztu" ${ }^{\prime 5}$. W związku z nierzadkimi przypadkami zaniedbywania obowiązku sporządzenia aktu chrztu, co wiązało się z moralnymi niedogodnościami dla ochrzczonego czy też jego rodziców, należałoby rozważyć wprowadzenie obowiązku powiadomienia ordynariusza o fakcie i miejscu sporządzenia aktu. Mógłby zostać do tego zobligowany szafarz, który wcześniej otrzymał zgodę na taki chrzest.

54 Zob. P. Krämer, Kirchenrecht I. Wort - Sakrament - Charisma, Stuttgart 1992, s. 83-85.

55 ICHAL, 23. 


\section{Zakończenie}

Podsumowując, należy stwierdzić, że udzielanie chrztu świętego małoletnim, którzy nie ukończyli 14. roku życia, w archidiecezji lubelskiej zostało uregulowane w statutach II Synodu Diecezji Lubelskiej oraz w Instrukcji o udzielaniu sakramentu chrztu w Archidiecezji Lubelskiej z dnia 28 kwietnia 2017 r., do której dołączono formularze kancelaryjne (załączniki).

Podstawą do udzielenia chrztu osobom poniżej 14. roku życia jest prośba lub zgoda wyrażona przynajmniej przez jednego z rodziców bądź prawnych opiekunów. W przypadku dzieci w wieku katechetycznym (7-14 lat) wymagana jest prośba lub zgoda przynajmniej jednego z rodziców lub prawnych opiekunów, jak również wyrażenie woli przyjęcia chrztu przez samego kandydata. Oznacza to, że poza sytuacją niebezpieczeństwa śmierci nie wolno ochrzcić dziecka bez wiedzy, a tym bardziej bez zgody rodziców lub opiekunów prawnych.

Miejscem udzielania chrztu dziecka jest parafia, w której zamieszkanie kanoniczne - stałe lub tymczasowe - posiadają rodzice. Jeśli nie mają oni wspólnego zamieszkania kanonicznego, właściwą parafią jest ta, na terenie której zamieszkuje rodzic z dzieckiem. Nie bierze się pod uwagę cywilnego zameldowania. Chrzest może być udzielony w innej parafii, jeśli rodzice uzyskają pisemne zezwolenie proboszcza parafii zamieszkania kanonicznego. Z zasady nie powinno się odmawiać takiego zezwolenia, jeśli jest ku temu słuszna przyczyna.

Podstawą do sporządzenia aktu chrztu jest cywilny skrócony odpis aktu urodzenia. Należy to uczynić w parafii, gdzie udzielono sakramentu. Odpowiedzialność za dokonanie tej czynności spoczywa na proboszczu i wiąże się z obowiązkiem odnotowania tego faktu w księdze ochrzczonych, prowadzonej w każdej parafii.

\section{Bibliografia}

\section{Źródła}

\section{Dokumenty Kościoła}

Catechismus Catholicae Ecclesiae, Città del Vaticano 1997. Katechizm Kościoła Katolickiego, wyd. 2, Poznań 2012.

Ordo baptismi parvulorum, editio typica, Typis Polyglottis Vaticanis 1969, 19732. Obrzedy chrztu dzieci wedtug Rytuatu Rzymskiego, Katowice 1972 oraz 
Obrzędy chrztu dzieci dostosowane do zwyczajów diecezji polskich, Katowice 1987², $1992^{3}, 1994^{4}$.

Sacrosanctum Concilium Oecumenicum Vaticanum II, Constitutio dogmatica de Ecclesia "Lumen gentium" (21.11.1964 r.), AAS 57(1965), s. 5-75. Sobór Watykański II, Konstytucje, dekrety, deklaracje, tekst polski, nowe tłumaczenie, red. M. Przybył, Poznań 2002.

Sacrosanctum Concilium Oecumenicum Vaticanum II, Decretum de activitate missionali Ecclesiae "Ad gentes Divinitus” (7.12.1965 r.), AAS 58(1966), s. 947-990. Sobór Watykański II, Konstytucje, dekrety, deklaracje, tekst polski, nowe tłumaczenie, red. M. Przybył, Poznań 2002.

Sacrosanctum Concilium Oecumenicum Vaticanum II, Decretum de apostolatu laicorum "Apostolicam actuositatem" (18.11.1965 r.), AAS 58(1966), s. 837-864. Sobór Watykański II, Konstytucje, dekrety, deklaracje, tekst polski, nowe tłumaczenie, red. M. Przybył, Poznań 2002.

Sacrosanctum Concilium Oecumenicum Vaticanum II, Decretum de presbyterorum ministerio et vita "Presbyterorum ordinis" (7.12.1965 r.), AAS 58(1966), s. 991-1024. Sobór Watykański II, Konstytucje, dekrety, deklaracje, tekst polski, nowe tłumaczenie, red. M. Przybył, Poznań 2002.

\section{Źródła prawa powszechnego i partykularnego}

II Synod Diecezji Lubelskiej 1977-1985, Lublin 1988.

Archiwum Kurii Metropolitalnej w Lublinie, Arcybiskup Metropolita Lubelski, Dekret zwołania III Synodu Archidiecezji Lubelskiej (Nr 171/Gt/2019).

Arcybiskup Metropolita Lubelski, Instrukcja o udzielaniu sakramentu chrztu w Archidiecezji Lubelskiej, Wiadomości Archidiecezji Lubelskiej „Memoranda” 2017, t. $91, \mathrm{nr} 2$.

Codex Iuris Canonici auctoritate Ioannis Pauli PP. II promulgatus (25.01.1983 r.), AAS 75(1983), pars II, s. 1-317. Kodeks Prawa Kanonicznego, przekład polski zatwierdzony przez Konferencje Episkopatu, Poznań 1984.

Codex Iuris Canonici Pii X Pontificis Maximi iussu digestus Benedicti Papae XV auctoritate promulgatus (27.05.1917 r.), AAS 9(1917), pars II, s. 1-593.

Formularze kancelaryjne do Instrukcji o udzielaniu chrztu w archidiecezji lubelskiej, Wiadomości Archidiecezji Lubelskiej „Memoranda” 2017, t. 91, nr 3.

Konferencja Episkopatu Polski, Dekret ogólny dotyczacy sporządzenia i modyfikacji aktu chrztu w związu z przysposobieniem (14.03.2017 r.), Akta Konferencji Episkopatu Polski 2018, nr 30.

Konferencja Episkopatu Polski, Instrukcja duszpasterska Episkopatu o udzielaniu sakramentu chrztu świętego dzieciom (1975), w: Dokumenty duszpastersko-liturgiczne Episkopatu Polski 1966-1993, oprac. C. Krakowiak, L. Adamowicz, Lublin 1994. 


\section{Literatura}

Adamowicz L., Wprowadzenie do prawa o sakramentach świętych wedtug Kodeksu Prawa Kanonicznego oraz Kodeksu Kanonów Kościołów Wschodnich, Lublin 1999.

Gerosa L., Prawo Kościoła, t. 12, Poznań 1999.

González Grenón J., La congruencia entre fe y vida para ser padrino de bautismo y de confirmación, Anuario Argentino de Derecho Canónico 2016, t. 22.

Krämer P., Kirchenrecht I. Wort - Sakrament - Charisma, Stuttgart 1992.

Krzywda J., Chrzest, w: W. Góralski i in., Komentarz do Kodeksu Prawa Kanonicznego, t. 3, cz. 2, ks. 4. Uświęcające zadanie Kościoła, cz. 1. Sakramenty, cz. 2. Pozostałe akty kultu Bożego, cz. 3. Miejsca i czasy święte, Poznań 2011.

Lombardía P., Arias J., Dekrety ogólne oraz instrukcje, w: Codex iuris canonici. Kodeks prawa kanonicznego. Komentarz. Powszechne i partykularne ustawodawstwo Kościoła katolickiego. Podstawowe akty polskiego prawa wyznaniowego, edycja polska na podstawie wydania hiszpańskiego, red. P. Majer, Kraków 2011.

Majer P., Tajemnica przysposobienia a przeszkoda pokrewieństwa: odnotowanie adopcji w księdze ochrzczonych (kan. 877 §3), Prawo Kanoniczne. Kwartalnik Prawno-Historyczny 2011, t. 54, nr 3-4.

Mikołajczuk K., Realizacja zasady jedności sakramentów wtajemniczenia chrześcijańskiego w prawodawstwie Kościoła Katolickiego, Kielce 2006.

Navarrete U., Responsa Pontificiae Commissionis Codici Iuris Canonici authentice interpretando, Periodica de Re Morali Canonica Liturgica 1988, t. 77.

Pawluk T., Prawo kanoniczne według Kodeksu Jana Pawła II, t. 1. Zagadnienia wstęne i normy ogólne, Olsztyn 2015.

Pawluk T., Prawo kanoniczne według Kodeksu Jana Pawła II, t. 2. Lud Boży jego nauczanie i uświęcanie, Olsztyn 2010.

Pylak B., Stowo wprowadzajace do Uchwat synodalnych, w: II Synod Diecezji Lubelskiej 1977-1985, Lublin 1988.

Rincón-Pérez T., La liturgia e i sacramenti nel diritto della Chiesa, Roma 2014.

Sitarz M., Miejsce instrukcji w hierarchii aktów normatywnych, w: O „Sanctorum Mater", red. W. Bar, L. Fiejdasz, Lublin 2008.

\section{Streszczenie}

Udzielanie chrztu świętego osobom, które nie ukończyły 14. roku życia, w archidiecezji lubelskiej zostało uregulowane w statutach II Synodu Diecezji Lubelskiej oraz w Instrukcji o udzielaniu sakramentu chrztu w Archidiecezji Lubelskiej z dnia 28 kwietnia 2017 r., do której dołączono formularze kancelaryjne (załączniki). Podstawą do udzielenia chrztu osobom poniżej 14. roku życia jest prośba lub zgoda wyrażona przynajmniej przez jednego z rodziców lub prawnych opiekunów. W przypadku dzieci w wieku katechetycznym (7-14 lat) 
wymagane jest również wyrażenie woli przyjęcia sakramentu przez samego kandydata. Na rodzicach i całym Kościele spoczywa obowiązek wychowania w wierze dzieci, które przyjęły chrzest, aby z czasem mogły ją osobiście wyznawać.

Słowa kluczowe: małoletni, synod diecezjalny, instrukcja, wychowanie w wierze

\title{
ADMINISTERING THE SACRAMENT OF BAPTISM TO PERSONS UNDER 14 YEARS OF AGE IN THE PARTICULAR LAW OF THE ARCHDIOCESE OF LUBLIN
}

\begin{abstract}
Sum mary
Baptism for those who are under the age of 14 in the Archdiocese of Lublin is governed by the statutes of the Second Synod of the Lublin Diocese and the Instructions on Baptism in the Archdiocese of Lublin of 28 April 2017, with appropriate attachments (the chancellery forms). The basis for baptism for persons under the age of 14 is a request or consent expressed by at least one of the parents or legal guardians. In the case of children of catechetical age (7-14 years), the candidate's expressed desire to receive the sacrament is also required. It is the responsibility of parents and the whole Church to give religious upbringing to children who have been baptized so that they may personally confess their faith in due time.
\end{abstract}

Key words: minor, diocesan synod, instructions, religious upbringing

\section{КРЕЩЕНИЕ ЛИЦ НИЖЕ 14-ОГО ГОДА ЖИЗНИ В ПАРТИКУЛЯРНОМ ПРАВЕ ЛЮБЛИНСКОЙ АРХИЕПАРХИИ}

\section{Резюме}

Крещение несовершеннолетних до 14 года жизни в Люблинской архиепархии регулируется уставами Второго Синода Люблинской епархии и Инструкцией по совершению таинства крещения в Люблинской архиепархии от 28 апреля 2017 года, к которой прилагаются формуляры (приложения). Обоснованием для совершения таинства крещения лица в возрасте до 14 лет является просьба или согласие как минимум одного родителя, или же лица, являющегося его законным опекуном. Для детей в катехуменальном возрасте (7-14 лет) требуется согласие на принятие таинства самого 
же кандидата. Родители и вся Церковь обязаны воспитывать в вере детей, принявших таинство крещения, чтобы впоследствии они лично могли её исповедовать.

Ключевые слова: несовершеннолетний, епархиальный синод, инструкция, воспитание в вере 